\title{
Extracellular Paracoccidioides brasiliensis phospholipase B involvement in alveolar macrophage interaction
}

\author{
Deyze Alencar Soares ${ }^{1}$, Rosângela Vieira de Andrade ${ }^{2}$, Simoneide Sousa Silva ${ }^{3}$, Anamélia Lorenzetti Bocca ${ }^{3}$,
} Sueli Maria Soares Felipe 2,3 , Silvana Petrofeza ${ }^{1 *}$

\begin{abstract}
Background: Phospholipase B (PLB) has been reported to be one of the virulence factors for human pathogenic fungi and has also been described as necessary for the early events in infection. Based on these data, we investigated the role of PLB in virulence and modulation of the alveolar pulmonary immune response during infection using an in-vitro model of host-pathogen interaction, i.e. Paracoccidioides brasiliensis yeast cells infecting alveolar macrophage (MH-S) cells.

Results: The effect of PLB was analyzed using the specific inhibitor alexidine dihydrochloride $(0.25 \mu \mathrm{M})$, and pulmonary surfactant $\left(100 \mu \mathrm{g} \mathrm{mL}{ }^{-1}\right)$, during 6 hours of co-cultivation of $P$. brasiliensis and MH-S cells. Alexidine dihydrochloride inhibited PLB activity by $66 \%$ and significantly decreased the adhesion and internalization of yeast cells by MH-S cells. Genes involved in phagocytosis (trl2, cd14) and the inflammatory response (nfkb, tnf- $\alpha$, il-1 $\beta$ ) were down-regulated in the presence of this PLB inhibitor. In contrast, PLB activity and internalization of yeast cells significantly increased in the presence of pulmonary surfactant; under this condition, genes such as clec2 and the pro-inflammatory inhibitor ( $n k r f$ ) were up-regulated. Also, the pulmonary surfactant did not alter cytokine production, while alexidine dihydrochloride decreased the levels of interleukin-10 (IL-10) and increased the levels of IL-12 and tumor necrosis factor- $\alpha$ (TNF- $\alpha$ ). In addition, gene expression analysis of p/b1, sod 3 and icl1 suggests that P. brasiliensis gene re-programming is effective in facilitating adaptation to this inhospitable environment, which mimics the lung-environment interaction.
\end{abstract}

Conclusion: P. brasiliensis PLB activity is involved in the process of adhesion and internalization of yeast cells at the $\mathrm{MH}-\mathrm{S}$ cell surface and may enhance virulence and subsequent down-regulation of macrophage activation.

\section{Background}

Paracoccidioidomycosis (PCM) is the most prevalent systemic mycosis in Latin America. Epidemiological data indicate a broad geographic distribution in Central and South America, from Mexico to Argentina [1]. It is estimated that as many as ten million individuals may be infected with $P$. brasiliensis in this part of the world. Infection occurs primarily in the lungs, from where it can disseminate via the bloodstream and/or lymphatic system to many organ systems, resulting in the disseminated form of PCM [2].

\footnotetext{
* Correspondence: petrofez@uol.com.br

'Instituto de Ciências Biológicas, Universidade Federal de Goiás, 74.001-940 Goiânia, GO, Brazil

Full list of author information is available at the end of the article
}

Considering the pathogenesis of this disease, the initial stages are of importance since this is when resident pulmonary macrophages interact with the fungus for the first time and become activated.

In this context, multiple characteristics have been proposed as virulence factors that enable the invading organism to cause disseminated infections in susceptible hosts. The ability to recognize and adhere to host tissues, to respond rapidly to changes in the external environment, and to secrete enzymes are all thought to play important roles in virulence. Secretion of enzymes, such as phospholipases, has been proposed as one of the strategies used by bacteria, parasites, and pathogenic fungi for invasion of the host and establishment of infection [3]. 
The role of extracellular phospholipases, particularly phospholipase B (PLB), as potential virulence factors for pathogenic fungi, including Candida albicans [4,5], Cryptococcus neoformans [6-10], and Aspergillus fumigatus [11] has been reported, although the underlying mechanism has yet to be elucidated. Extracellular phospholipase activities have also been detected in in-vitro cultures of P. brasiliensis [12], and PLB has been postulated as a potential virulence factor for this pathogen by in-silico analysis [13].

Phospholipases are ubiquitous enzymes that are involved in a wide range of biological functions, such as membrane homeostasis, nutrient acquisition, and generation of bioactive molecules. These enzymes are known to contribute to bacterial and fungal virulence through a variety of different interactions with eukaryotic host cells, [14] and to modulate the innate and acquired immune response of the host by generating second messengers such as diacylglycerol or the eicosanoid precursor arachidonic acid [15]. Furthermore, phospholipase-mediated IL-8 release induces the host inflammatory response [14].

It has been shown that secreted PLB1, a proven virulence determinant of $C$. neoformans, is required for the initiation of interstitial pulmonary cryptococcosis, being important for the binding of this fungus to human lung epithelial cells prior to its internalization [9]. PLB1, the product of the CnPLB1 gene, is a multifunctional enzyme which can degrade dipalmitoylphosphatidylcholine (DPPC), the main component of lung surfactant [7].

The goal of this work was to determine whether $P$. brasiliensis PLB is involved in adhesion of this fungus to and internalization by alveolar macrophage (MH-S) cells. Also, we investigated the role of this enzyme in virulence and modulation of the alveolar pulmonary immune response during infection using alexidine dihydrochloride as a specific PLB inhibitor, as well as pulmonary surfactant (Survanta) as a substrate rich in phospholipids.

\section{Results and discussion}

The first contact between P.brasiliensis and the host occurs by inhalation of the infectious propagules from the environment. PLB has been reported as a potential virulence factor by transcriptome analysis in P. brasiliensis $[13,16]$. Furthermore, experiments performed by our group showed that the $p l b 1$ gene is up-regulated during the early events of murine pulmonary infection in a paracoccidioidomycosis model (data not shown), suggesting a possible role for this enzyme in the host-pathogen interaction and reinforcing the hypothesis that PLB could be an important virulence factor for $P$. brasiliensis.

In C. neoformans, PLB is necessary for the early events of pulmonary infection and for dissemination from the lung via the lymphatic system and blood $[9,17]$.
Specifically, adhesion to alveolar macrophage cells is reduced in a PLB deletion mutant of $C$. neoformans and also in the presence of selective chemical inhibitors of PLB and a specific anti-PLB antibody. The extent of adhesion was correlated with PLB activity, but not with lysophospholipase (LPL) or lysophospholipase transacylase (LPTA) activity [9].

Lack of established protocols for conducting experiments that might lead to gene disruption or silencing in $P$. brasiliensis hinders the validation of the $p l b$ gene functionality in this pathogen. In view of this fact, we decided to investigate the role of PLB using an in-vitro model of host-pathogen interaction, i.e. the yeast cells of $P$. brasiliensis infecting MH-S cells. The use of a specific inhibitor and/or an activator of PLB could be an effective strategy for investigating the possible role of this enzyme during host-pathogen interaction.

\section{Effects of alexidine dihydrochloride and pulmonary surfactant on cell viability, adhesion, internalization, and PLB activity during co-cultivation of P. brasiliensis and MH-S cells}

In order to verify whether the treatment with alexidine dihydrochloride and pulmonary surfactant interferes with cell viability, colony-forming unit (CFU) analysis was performed after co-cultivation of $P$. brasiliensis and MH-S cells. Cell viability of $P$. brasiliensis was evaluated by CFU analysis after treatment with the PLB inhibitor $(0.25 \mu \mathrm{M}$ alexidine dihydrochloride) and $100 \mu \mathrm{g} \mathrm{mL}^{-1}$ pulmonary surfactant. The percentage of cell viability was not significantly altered $6 \mathrm{~h}$ post-infection (Figure 1A).

To further investigate the role of PLB we evaluated the percentage of $P$. brasiliensis yeast cells adhered to or internalized by $\mathrm{MH}-\mathrm{S}$ cells after pulmonary surfactant and alexidine dihydrochloride treatments. The addition of $100 \mu \mathrm{g} \mathrm{mL}^{-1}$ pulmonary surfactant increased PLB activity by $28 \%$ (Table 1 ), leading to a strong positive effect on the internalization of $P$. brasiliensis (Figure $1 \mathrm{~B})$, at least a 3 -fold increase in comparison with the control. Also, the proportion of internalized yeast cells (23\%) was higher than the proportion of yeast cells adhered to macrophage surfaces $(6 \%)$. In contrast, we found that $0.25 \mu \mathrm{M}$ alexidine dihydrochloride caused an 8 -fold inhibition in the levels of phagocytosis by MH-S cells compared with the control (Figure 1B). No effects of alexidine dihydrochloride or pulmonary surfactant on adhesion and internalization of heat-killed $P$. brasiliensis were observed (data not shown).

A role for PLB activity in adhesion of C. neoformans to lung epithelial cells has already been proposed [9]; DPPC is predicted to be the favored lipid substrate for PLB, leading to the production of glycerophosphocholine and free palmitic acid. In this context, it is hypothesized that the addition of pulmonary surfactant (rich in 


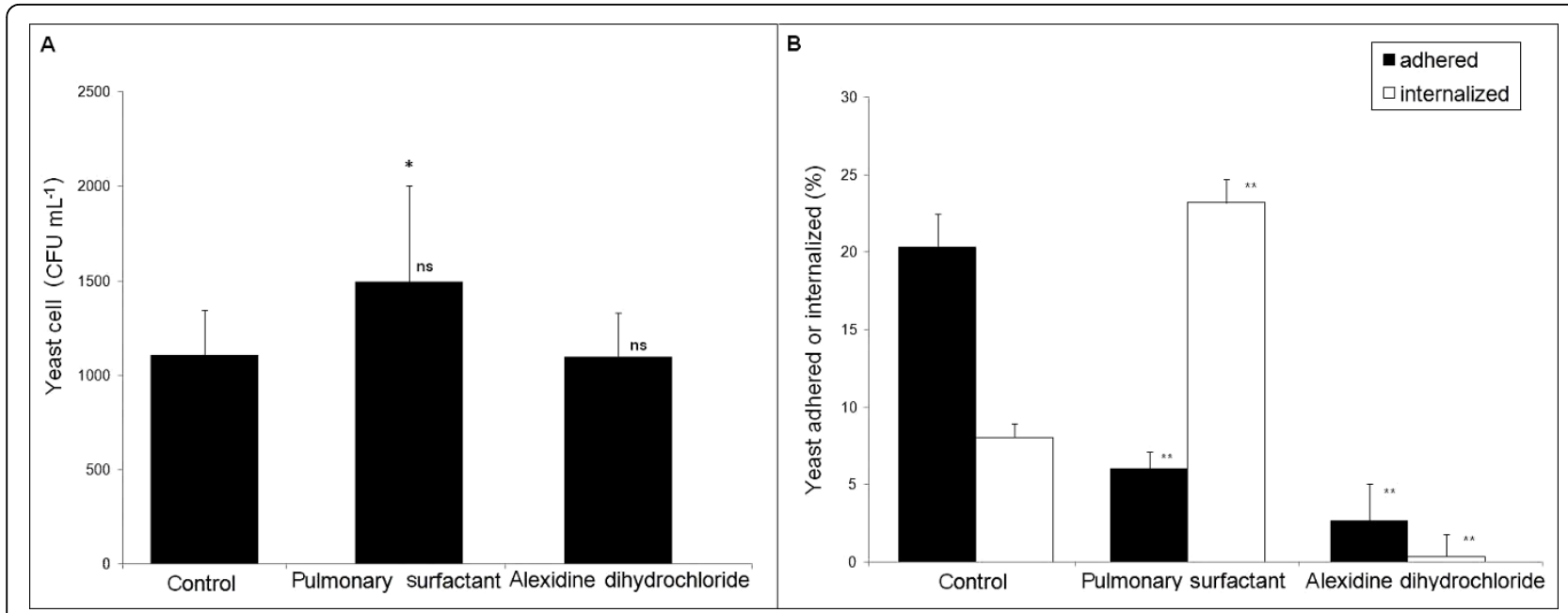

Figure 1 Paracoccidioides brasiliensis isolate $\mathrm{Pb} 18$ yeast cell viability and infection index after co-culture with alveolar macrophage (MH-S) cells. (A) CFU of P. brasiliensis isolate Pb18 yeast cells; (B) Infection index of in-vitro MH-S cells in the presence of alexidine dihydrochloride $(0.25 \mu \mathrm{M})$ and pulmonary surfactant $\left(100 \mu \mathrm{g} \cdot \mathrm{mL}^{-1}\right)$. Percentage of MH-S cells infected with $P$. brasiliensis yeast cells - adhered (black bar) or internalized (white bar). In all experiments, $\mathrm{MH}-\mathrm{S}$ cells and opsonized yeast cells were incubated at a yeast-to-macrophage ratio of $1: 5$, at $37^{\circ} \mathrm{C}$ in an atmosphere of $5 \% \mathrm{CO}_{2}$ as described in the Materials and Methods. Data shown are derived from two in-vitro independent experiments performed in triplicate (mean $\pm S E M$, with ${ }^{*}$ significance assumed in the range of $P<0: 05$ ); $n s=$ non-significantly $(P<0.05)$; **Significantly different from the untreated control $\mathrm{P}<0.001$ by the paired 2-tailed Student's $t$-test.

DPPC) would increase the adhesion of $P$. brasiliensis yeast cells to $\mathrm{MH}-\mathrm{S}$ cells. These results strongly suggest that PLB activity is important in P. brasiliensis adhesion to and/or internalization by $\mathrm{MH}-\mathrm{S}$ cells.

In the present study, enzyme activities were tested under conditions used for adhesion (Table 1). P. brasiliensis produced high levels of PLB at $6 \mathrm{~h}$ post-infection. $0.25 \mu \mathrm{M}$ Alexidine dihydrochloride selectively inhibited PLB activity by $66 \%$. In contrast, PLB activity in the presence of $100 \mu \mathrm{g} \mathrm{mL}^{-1}$ pulmonary surfactant was significantly increased (28\%) compared to the control experiment.

Modulation of $\mathrm{P}$. brasiliensis and $\mathrm{MH}-\mathrm{S}$ genes in the hostpathogen interaction

Real-time quantitative reverse-rranscriptase-polymerase chain reaction (qRT-PCR) analysis confirmed that the

Table 1 Phospholipase B activities secreted under the experimental conditions used for Phagocytic test

\begin{tabular}{|c|c|}
\hline Treatment & $\begin{array}{l}\text { Specific activity of PLB } \\
\left(\mu \mathrm{mol} \mathrm{min}^{-1} \mathrm{mg}^{-1} \text { protein }\right)\end{array}$ \\
\hline Untreated control & $1.21 \pm 0.02$ \\
\hline Pulmonary surfactant $\left(100 \mu \mathrm{g} \mathrm{mL}^{-1}\right)$ & $1.55 \pm 0.06^{*}$ ( $28 \%$ activation) \\
\hline Alexidine dihydrochloride $(0.25 \mu \mathrm{M})$ & $0.41 \pm 0.08^{*}(66 \%$ inhibition $)$ \\
\hline
\end{tabular}

Phospholipase $\mathrm{B}$ activities were assayed after $6 \mathrm{~h}$ of co-cultivation of alveolar macrophage (MH-S) cells with $P$. brasiliensis yeast cells with pulmonary surfactant $\left(100 \mu \mathrm{g} \mathrm{mL}^{-1}\right)$ and alexidine dihydrochloride $(0.25 \mu \mathrm{M})$, as well as without treatment (untreated control), as described in Materials and Methods. *Significantly different from the untreated control, $\mathrm{P}<0.05$ by the paired 2tailed Student's $t$-test. Results are means \pm SEM of triplicate assays. plb1 (PLB), sod3 (Cu, Zn superoxide dismutase - SOD), and icl1 (isocitrate lyase) genes were up-regulated in $P$. brasiliensis yeast cells during $6 \mathrm{~h}$ of interaction with $\mathrm{MH}-\mathrm{S}$ cells in the presence of pulmonary surfactant. The sod3 gene presented a 4.1-fold increase in expression (Figure 2) and under these conditions a higher percentage of yeast cell internalization was observed (Figure 1B). In addition, the $\mathrm{i} c l 1$ and plb1 genes presented 7.4-fold and 2-fold increases in their transcripts levels, respectively. However, in the presence of alexidine dihydrochloride, the levels of transcripts strongly decreased, reaching 0.3-, 0.8- and 1.8-fold for plb1, sod 3 , and icl1, respectively (Figure 2).

P. brasiliensis metabolic adaptation in response to phagocytosis involves the induction of sod3, which encodes a putative $\mathrm{Cu}, \mathrm{Zn}$ SOD, an enzyme participating in the elimination of superoxide anions. In-silico analysis showed that $P$. brasiliensis sod 3 corresponds to a putative membrane-bound, glycosylphosphatidylinisotol (GPI)-anchored $\mathrm{Cu}, \mathrm{Zn} \mathrm{SOD}$, which would allow for better accessibility to host-derived superoxide anions and subsequent rapid detoxification of reactive oxygen intermediates (ROI) [18,19]. The up-regulation of sod3 expression in $P$. brasiliensis internalized by pulmonary surfactant-treated $\mathrm{MH}-\mathrm{S}$ cells provides evidence that sod3 may also be needed for the elimination of generated superoxides, thus increasing yeast cell survival. This suggests that the sod3 gene is probably involved in the survival of $P$. brasiliensis, corroborating previous data [18]. 


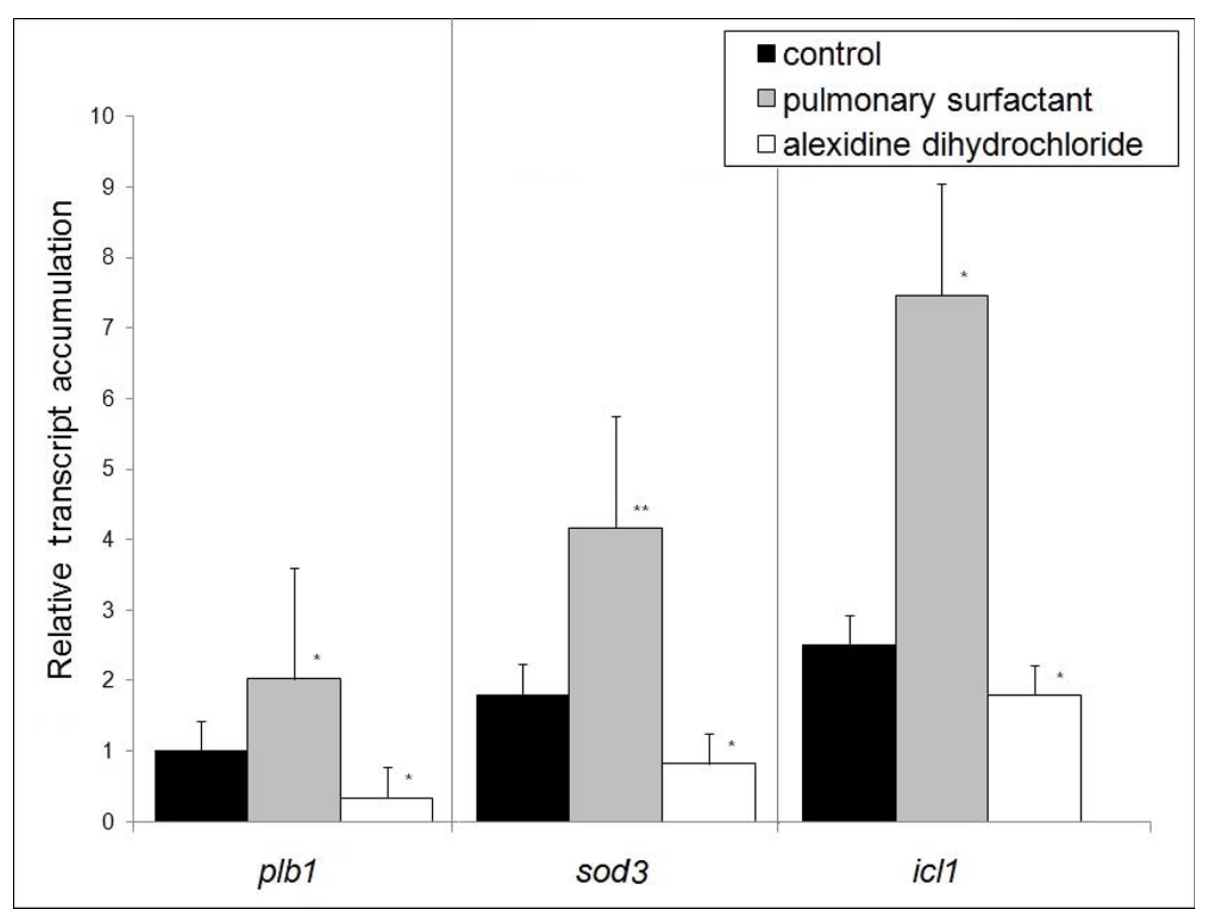

Figure 2 Real-Time RT-PCR. Analysis of the transcript level of Paracoccidioides brasiliensis genes related to oxidative stress - superoxide dismutase (sod3); metabolism - isocitrate lyase (ic/1) and hydrolytic enzyme phospholipase B (p/b1). The assay was carried out in triplicate (mean \pm SEM); Significantly different from controls: $\left({ }^{*} \mathrm{P}<0: 05\right.$ and $\left.{ }^{* *} \mathrm{P}<0: 001\right)$ by the paired 2-tailed Student's $t$-test.

Induction of the glyoxylate cycle upon phagocytosis has been described as an important adaptation by pathogens to the glucose-poor environment within macrophages, since it facilitates the assimilation of twocarbon compounds, the product of fatty acid degradation [20,21]. In P. brasiliensis, both isocitrate lyase and the entire glyoxylate pathway have been shown to be enhanced under low glucose and oxygen tension, in the presence of acetate and high temperature, as well as during intracellular growth $[16,22,23]$. Our results showed that the icl1 gene was up-regulated under increased PLB activity, which could be correlated with the fungal survival inside macrophage cells.

The results observed for the gene expression of plb1, sod3, and icl1 suggest that, under in-vitro conditions mimicking the lung-environment interaction, gene re-programming was similar to that described for peritoneal macrophages $[18,24]$, corroborating the importance and effective participation of those genes in the process of adaptation by the fungus to this inhospitable environment.

The process of recognition of pathogen-associated molecular patterns (PAMP) depends on the pattern recognition receptors (PRR) present in great diversity in the plasma membrane of phagocytes [25]. The two main members of this family that recognize fungal components are the C-type lectin-like receptors (CLRs) and toll-like receptors (TLRs) [26].
To investigate whether $P$. brasiliensis PLB is able to affect the inflammatory response of $\mathrm{MH}$-S cells, we assessed the transcription level of the following key genes: thf- $\alpha$ (tumor necrosis factor-alpha), il-1 $\beta$ (Interleukin-1 $1 \beta$ ), $n k r f$ (NFKappaB repressing factor), and $n f k b$ (P50 subunit of NFKappaB), known to be involved in the phagocytic process, and trl2 (toll-like receptor 2), cd14 (glycosyl-phosphatidylinositol-anchored glycoprotein), and clec2 (C-type lectin-like receptor), signal receptors involved in controlling the immune response. These genes had already been reported to be differentially expressed by peritoneal macrophages infected with P. brasiliensis [24].

In our experiments, $\operatorname{trl} 2, c d 14, I l-1 \beta, n f k b$, and $\operatorname{tnf-\alpha }$ genes, which play an important role in the host innate response, were down-regulated during $P$. brasiliensis$\mathrm{MH}-\mathrm{S}$ cell interaction in the presence of pulmonary surfactant or alexidine dihydrochloride compared to the control (Figure 3). In contrast, the main up-regulated genes were those encoding the membrane-related protein CLEC 2 (clec2) - a mannose-type receptor, important for more effective phagocytic capacity [27] - and the pro-inflammatory inhibitor $(n k r f)$, presenting foldchanges of 8.0 and 9.8 respectively, in cultures exposed to the pulmonary surfactant (Figure 3).

NFkB is a key transcription factor involved in TLRmediated innate immunity and together with its 


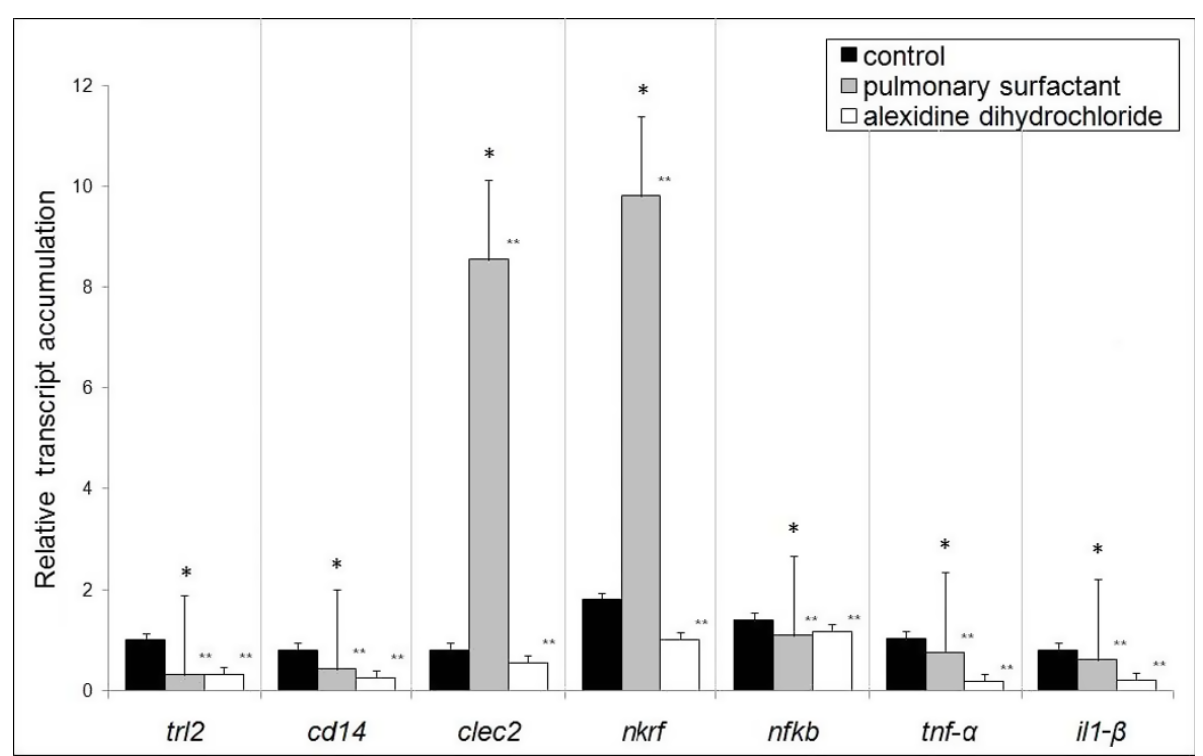

Figure 3 Real-Time RT-PCR. Analysis of the transcript level of macrophage genes related to phagocytosis (clec2, tr/2, and $c d 14)$ and inflammation (nkrf, nfkb, tnf- $\alpha$, and $i l-1 \beta$ ). The assay was carried out in triplicate (mean $\pm \mathrm{SEM}$, with *significance assumed in the range of $\mathrm{P}<$ $0: 05) ;{ }^{*}$ Significantly different from controls: $P<0.001$ by the paired 2-tailed Student's $t$-test.

repressor Nkrf is an important regulator of the inflammatory process, a powerful protective mechanism coordinated and controlled by cytokines and chemokines. Our data showed an up-regulation of the $n k r f$ gene in the presence of the pulmonary surfactant, suggesting a possible modulation of the innate immune response under conditions of increased PLB activity.

\section{Cytokine production by MH-S cells during host-pathogen interaction}

In order to verify the pattern of MH-S cell activation, the levels of the cytokines interleukin-10 (IL-10), IL-12, and tumor necrosis factor- $\alpha$ (TNF- $\alpha$ ) were determined. When compared to the control, the MH-S cells treated with alexidine produced higher levels of IL-12 and TNF$\alpha$ and lower levels of IL-10. However, no significant difference between the control group and the group treated with surfactant was observed (Figure 4).

In the course of experimental fungus infection, cellmediated immunity is critical for host defense [28]. The successful resolution of $P$. brasiliensis infection depends on a strong Th1 immune response and downregulation of Th2 cytokine production. The immune response involving a preferential Th1 activation, with IFN- $\gamma$ production and efficient macrophage activation, is able to control fungal dissemination. IFN- $\gamma$ production is partly dependent on IL-12 production in macrophages [29].

Our results demonstrated that the interaction between $\mathrm{MH}-\mathrm{S}$ and yeast cells, in the presence of PLB, is capable of shaping macrophage activation, compromising the induction of the Th1 response and strongly suggesting a pathogen evasion mechanism.

Based on these results, we propose the model presented in Figure 5 to explain the phagocytic mechanism of the interaction between P. brasiliensis and MH-S cells. In the presence of the activator of PLB activity (pulmonary surfactant), a stimulation of the mannose-receptor CLEC signal transduction pathway probably occurs, since expression of this gene is induced. The up-regulated clec2 and $n k r f$ and the down-regulated $n f k b, t n f-\alpha$, and $i l-1 \beta$ genes provide evidence that the mannose-receptor CLEC is the probable mediator of fungal phagocytosis. This is further supported by the increased adherence and internalization of yeast cells by $\mathrm{MH}-\mathrm{S}$ cells in the presence of the surfactant. Also, the trl2 and $c d 14$ genes are downregulated, reinforcing the hypothesis that phagocytosis is probably occurring via the CLEC mannose receptor. In contrast, in the presence of the inhibitor of PLB - alexidine dihydrochloride -, the clec 2 and $n k r f$ genes are repressed, which also corroborates this hypothesis. Furthermore, adhesion and internalization are stimulated and, consequently, a gene expression re-programming occurs regarding the genes involved in the survival of the pathogen inside the MH-S cells.

Fungal PLB exhibits a function related to the regulation of immune responses via the liberation of fatty acid precursors (arachidonic acid, linolenic acid, or eicosanopentaenoic acid) for host eicosanoid synthesis [15]. The production of eicosanoids, potent regulators of host immune responses, including prostaglandins and leukotrienes by fungi in the lungs, may also play a role in 


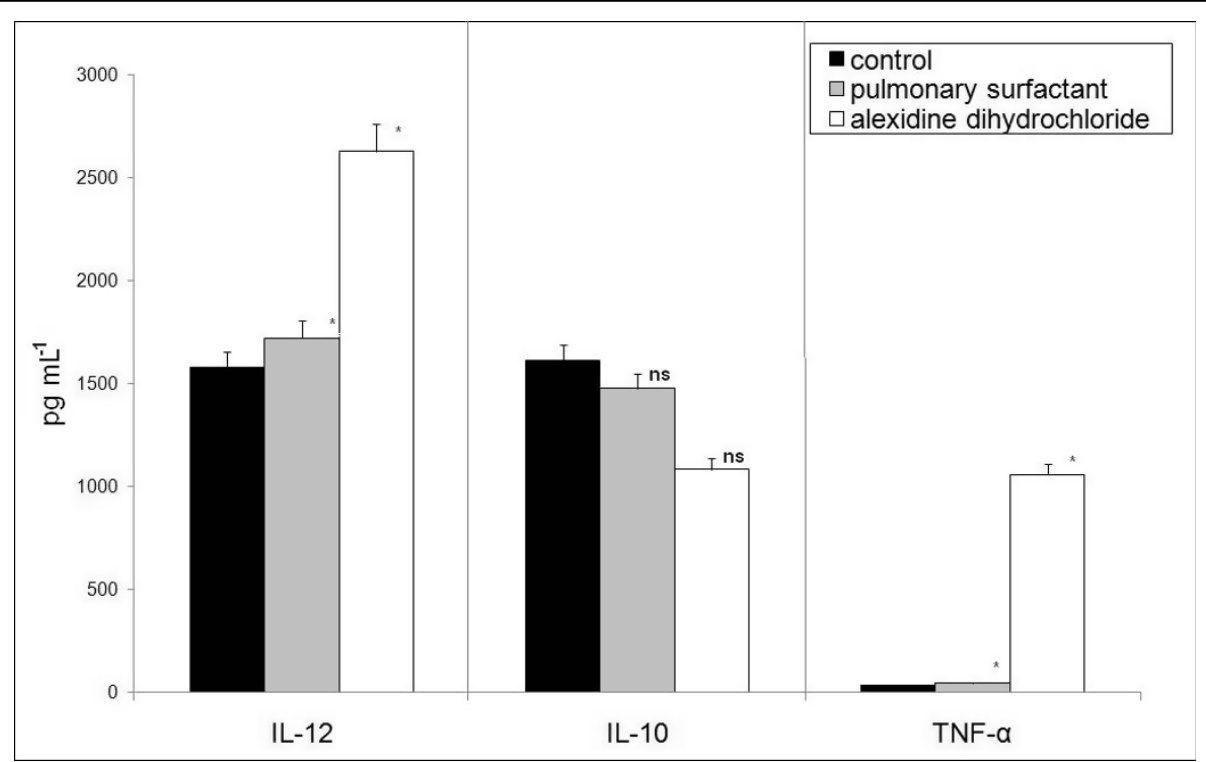

Figure 4 Amount of cytokines and tumor necrosis factor- $\alpha$ released by alveolar macrophage (MH-S) cells infected with Paracoccidioides brasiliensis. The assay was carried out in triplicate (mean \pm SEM); ns = non-significantly and ${ }^{*}$ significantly different from controls: $\mathrm{P}<0.05$ by the paired 2-tailed Student's t-test.

modulating the Th1-Th2 balance in the immune response, and may promote eosinophil recruitment or survival of the fungus in the lungs [15]. In-vivo and ex-vivo P. brasiliensis infection has been recently proven to induce leukotriene synthesis, which could explain the low levels of cytokines IL-10, IL-12, and TNF- $\alpha$, and confirm a pattern

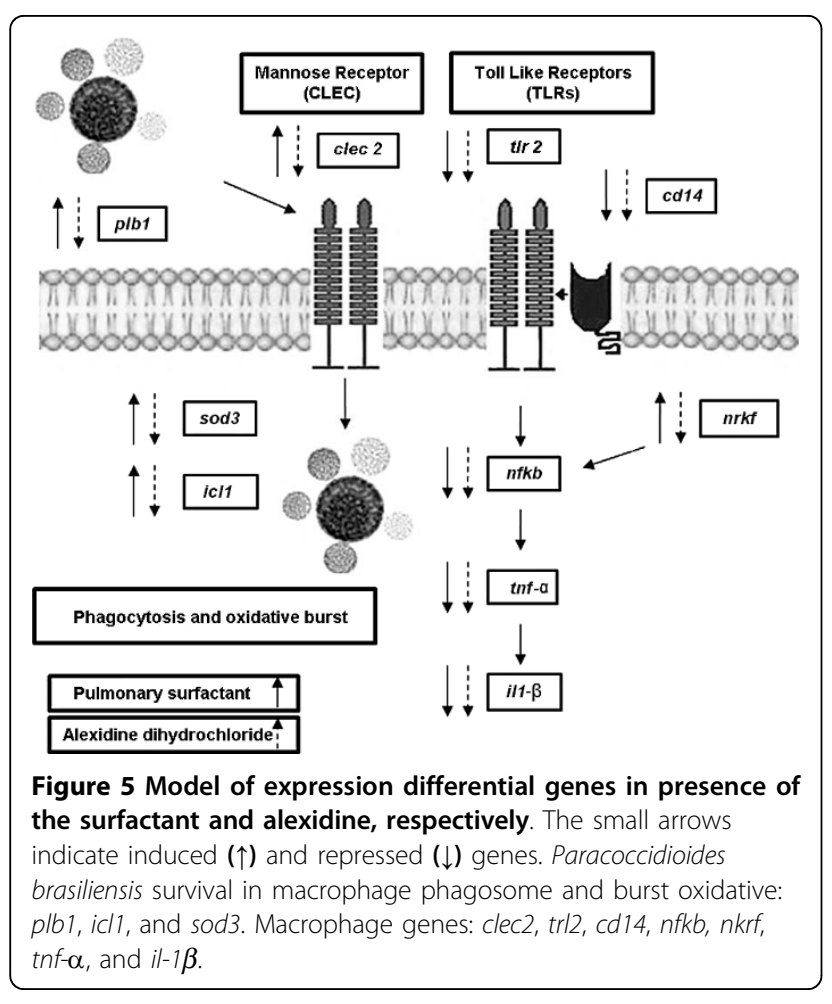

capable of interfering in the host response to the fungus [30]. Thus, in the presence of surfactant there is increased activity of PLB, and probably a greater release of substrates for lipid synthesis and production of leukotrienes, which act as suppressors of the innate immune response, confirming the low expression levels of the cytokine tnf- $\alpha$ and $i l-1 \beta$ genes. In the proposed model, the genes related to phagocytosis and oxidative burst are up-regulated providing an efficient mechanism for fungal survival. The increase in IL-12 and decrease in IL-10 after inhibition of PLB participate in the enhancement of IFN $-\gamma$ activity, which is capable of inducing a cellular immune response. These data confirm the participation of PLB in the mechanism of fungal evasion, interfering with an adequate immune response by the host.

\section{Conclusions}

Based on these data, we conclude that $P$. brasiliensis PLB is important for adhesion and internalization of yeast cells by MH-S cells. Whether PLB activity results from the production of eicosanoids or leukotrienes or not remains unknown, although studies are in progress to investigate this possibility. Nevertheless, our study clearly identified activities of fungal PLB that may enhance virulence and subsequent down-regulation of macrophage activation.

\section{Methods}

\section{Strains, cultures and reagents}

P. brasiliensis Pb18 (ATCC 32069) yeast cells were cultivated in Fava-Netto semisolid medium for 7 days at $37^{\circ}$ $\mathrm{C}$ and used in in-vitro infection. Alveolar macrophage 
lineage MH-S (ATCC CRL-2019) was grown in RPMI1640 tissue culture medium (Sigma-Aldrich, Inc., St. Louis, MO, USA) supplemented with $20 \mathrm{mM}$ HEPES, $1.5 \mathrm{~g} \mathrm{~L}^{-1}$ sodium bicarbonate, $2.5 \mathrm{mg} \mathrm{mL}^{-1}$ gentamicin, and $10 \mathrm{U} \mathrm{mL}^{-1}$ heparin. The viability of $\mathrm{MH}-\mathrm{S}$ cells was determined by trypan blue exclusion. All assays used the bovine pulmonary surfactant Survanta (Abbott Laboratories, Inc., Columbus, OH, USA), which is an extract of bovine lung containing about $75 \%$ DPPC and $45 \%$ phosphatidylcholine $(\mathrm{PC})$, generating substrates for phospholipases. The specific inhibitor of PLB - alexidine dihydrochloride (Toronto Research Chemicals, Inc., Toronto, Ontario, Canada) - was prepared as a stock solution at $10 \mathrm{mM}$ in dimethyl sulfoxide (DMSO), which was then diluted to the required concentration with RPMI medium.

\section{Infection of MH-S cells with P. brasiliensis yeast cells Phagocytic test}

$\mathrm{MH}-\mathrm{S}$ cells were seeded in 24 -well $\left(0.2 \times 10^{5}\right.$ cells/well $)$ or in $150 \mathrm{~cm}^{2}\left(0.4 \times 10^{7}\right.$ cells/well $)$ cells culture flasks and incubated at $37^{\circ} \mathrm{C}$ for $6 \mathrm{~h}$. Non-adherent cells were removed by washing, whereas the adherent cells were incubated in RPMI supplemented as stated above, with $10 \%$ heat-inactivated fetal calf serum, at $37^{\circ} \mathrm{C}$. P. brasiliensis yeast cells were suspended in RPMI medium containing $20 \%$ fresh mouse serum. The opsonization protocol was carried out by incubation of yeast cell suspension at $37^{\circ} \mathrm{C}$ for $30 \mathrm{~min}$. MH-S cell monolayers were infected with $4 \times 10^{6}$ yeast cells, representing a yeast-tomacrophage ratio of 1:5 [31]. Incubation was carried out at $37^{\circ} \mathrm{C}$ in a humidified $5 \% \mathrm{CO}_{2}$ atmosphere.

The influence of PLB on the phagocytic indices was evaluated by adding different concentrations of the surfactant $\left(100 \mu \mathrm{g} \mathrm{mL}^{-1}\right.$ and $\left.200 \mu \mathrm{g} \mathrm{mL} \mathrm{L}^{-1}\right)$ and alexidine dihydrochloride $(0.25 \mu \mathrm{M}$ and $0.50 \mu \mathrm{M})$ to the culture medium at the beginning (T0) of the experiments.

We selected a 6-hour period for infection because it represents an early time point of fungal cell internalization by macrophages [18]. After infection, the culture was fixed with methanol and stained with WrightGiemsa (Sigma-Aldrich, Inc., St. Louis, MO, USA). $P$. brasiliensis cells were counted in order to evaluate the percentage of attached or internalized yeast cells after infection. Experiments were performed in triplicate, and 12 microscopic fields were assessed. The results are presented as mean \pm SEM (standard error of the mean).

\section{Colony forming unit (CFU) determination}

The number of viable fungal cells after phagocytosis by $\mathrm{MH}-\mathrm{S}$ cells was assessed by CFU counts. MH-S cells were challenged with $P$. brasiliensis yeast cells and incubated for $6 \mathrm{~h}$ as described for the phagocytic test. After this time, cultures were rinsed with RPMI to remove non-internalized yeast cells and distilled water was added to lyse the macrophages. The cellular suspension was harvested, washed in phosphate buffered saline (PBS), and the final pellets were resuspended in $1 \mathrm{~mL}$ of PBS. Aliquots of $100 \mu \mathrm{L}$ of each sample were added to agar plates (4\% SFB, 5\% BHI solid medium) and colonies per plate were counted after 8-10 days of incubation at $37^{\circ} \mathrm{C}$.

\section{RNA extraction}

Total RNA from P. brasiliensis yeast cells internalized by MH-S cells and RNA from MH-S cells were extracted after $6 \mathrm{~h}$ of co-cultivation with pulmonary surfactant $\left(100 \mu \mathrm{g} \mathrm{mL}^{-1}\right)$ and alexidine dihydrochloride $(0.25 \mu \mathrm{M})$, as well as without treatment (control). Extracellular and weakly adherent fungal cells were removed by washing with pre-warmed RPMI. Macrophages were then lysed with a guanidine thiocyanate-based solution [32] and intact fungal cells were harvested by centrifugation $(8000 \times g$ for $10 \mathrm{~min})$ immediately followed by Trizol total RNA extraction (Invitrogen Corp., Carlsbad, CA, USA) according to the manufacturer's instructions. Total RNA from in-vitro grown $P$. brasiliensis yeast cells and $\mathrm{MH}-\mathrm{S}$ cells was also extracted with Trizol, to be used as controls.

\section{Phospholipase B assay}

Supernatants were obtained after cell centrifugation at $10000 \times g$ for 15 min and assayed for PLB activity using DPPC as a substrate by the radiometric assay method [7]. The carriers, DPPC $(800 \mathrm{mM})$ and $1,2-\mathrm{di}\left[1-{ }^{14} \mathrm{C}\right]$ palmitoyl-phosphatidylcholine $(20,000 \mathrm{dpm})$, were dried under nitrogen and resuspended in $125 \mathrm{mM}$ imidazoleacetate buffer, $\mathrm{pH}$ 4.0. The reaction was initiated by adding culture supernatant (1 $\mathrm{mg}$ of total protein), and

Table 2 Primers Paracoccidioides brasiliensis used for real time RT-PCR

\begin{tabular}{|c|c|c|c|}
\hline Cluster ID ${ }^{a}$ & Gene $^{\text {b }}$ & Forward primer $\left(5^{\prime}-3^{\prime}\right)$ & Reverse primer $\left(5^{\prime}-3^{\prime}\right)$ \\
\hline 50 & sod3 & CTGTTCGCTGGGCTITGC & TCAGTAGTGACGGCTTCCATCAT \\
\hline 1688 & icll & GCTCACCCAGATGGTCAAAT & AGTATCCGCATCCGCAATAA \\
\hline 3306 & plb1 & GCAATGCAAGGGAAGAAAGA & CGATCCGAGGAACTCTAACG \\
\hline
\end{tabular}

a ID: identification.

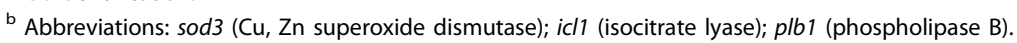


Table 3 Primers for real time RT-PCR to measure gene expression using RNA from alveolar macrophage (MH-S) cells

\begin{tabular}{|c|c|c|c|}
\hline Cluster ID ${ }^{a}$ & Gene $^{\text {b }}$ & Forward primer $\left(5^{\prime}-3^{\prime}\right)$ & Reverse primer $\left(5^{\prime}-3^{\prime}\right)$ \\
\hline 272294 & Rps9 & CGCCAGAAGCTGGGTTTGT & CGAGACGCGACTTCTCGAA \\
\hline 21961 & $n k r f$ & ACCTITCAACCTACGATGGTCAGA & GAGCTCTCACATGGAATTTGGAA \\
\hline 575033 & $n f k b$ & AGCCAGCTTCCGTGTTTGT & AGGGTTTCGGTTCACTAGTTTCC \\
\hline 104798 & $\operatorname{tnf}-\alpha$ & GTACCTTGTCTACTCCCAGGTTCTCT & GTGGGTGAGGAGCACGTAGTC \\
\hline 574821 & clec2 & CTCTTCTTGGTGGCGTGTGA & AACAACCAGCCCCATGGA \\
\hline 3989461 & $i l-1 \beta$ & GTGTGTGACGTTCCCATTAGACA & CAGCACGAGGCTIITTGTTG \\
\hline 1346060 & $\operatorname{tr} 12$ & AAGAGGAAGCCCAAGAAAGC & CGATGGAATCGATGATGTTG \\
\hline 5120996 & cd14 & CGCAGCCTGGAATACCTTCTA & CCGCTTTAAGGACAGAGACTTGATA \\
\hline
\end{tabular}

a ID: identification.

${ }^{\mathrm{b}}$ Abbreviations: Rps9 (constitutive ribosomal macrophage gene); $n k r f$ (NFKappaB repressing factor); $n f k b$ (P50 subunit of NFKappaB); tnf- $\alpha$ (tumor necrosis factor-

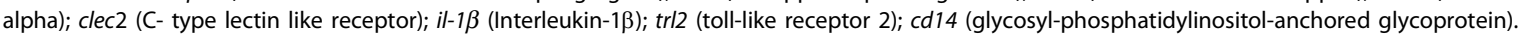

after incubation for $30 \mathrm{~min}$ the rate of radiolabeled PC loss was measured.

Reaction products were extracted, separated by thinlayer chromatography (TLC), and quantified. Measurements were repeated in three experiments for each treatment and the data were presented as the average of the three. PLB activity was expressed as $\mathrm{mM}$ of substrate hydrolyzed per minute, per milligram of protein. Total protein concentrations were measured using the Protein Assay kit (Quant-iT - Invitrogen Corp., Carlsbad, CA, USA). Significance tests were carried out comparing each treatment with the control value $(100 \%)$ using a one-sample Student's $t$-test. $P<0.05$ was taken as the limit to indicate significance.

\section{Real-time RT-PCR validation of differentially expressed genes}

The real-time RT-PCR system using SYBR Green detection (Applied Biosystems) was used to analyze gene expression in RNA samples. After treatment with DNase I (Invitrogen Corp., Carlsbad, CA, USA) in the presence of RNase inhibitor (Invitrogen Corp., Carlsbad, CA, USA), equal amounts of RNA $(1 \mu \mathrm{g})$ were reverse transcribed using oligo(dT)12-18 primer and submitted to real time PCR. Amplification assays were carried out with a 7900HT Sequence Detection System ABI PRISM instrument (Applied Biosystems, Carlsbad, CA, USA) in $12 \mu \mathrm{L}$ reactions containing $0.4 \mu \mathrm{M}$ of each primer (listed in Tables 2 and 3), $6 \mu \mathrm{L}$ of SYBR Green PCR Master mix $(2 \times)$, and $0.2 \mu \mathrm{L}$ of template cDNA. After initial denaturation at $95^{\circ} \mathrm{C}$ for $10 \mathrm{~min}$, amplifications were performed for 40 cycles of: $95^{\circ} \mathrm{C}$ for $15 \mathrm{~s}$ followed by $60^{\circ} \mathrm{C}$ for $1 \mathrm{~min}$.

The comparative crossing threshold (CT) method, employing the constitutive ribosomal Rps 9 macrophage gene or $P$. brasiliensis $\alpha$-tubulin gene, was used in order to normalize the expression value of each gene of interest in the macrophage infected sample compared with the non-infected control. Real time RT-PCR experiments were carried out in triplicate for all analyzed genes.

\section{Analysis of cytokine secretion by MH-S cells}

Supernatants of co-cultured cells from the different treatments, obtained as described above, were used for the detection of cytokine production. The levels of cytokines IL-10, IL-12, and TNF- $\alpha$ were measured using a commercial ELISA kit (BD Biosciences, San Diego, CA, USA) according to the manufacturer's guidelines. The cytokine levels in the supernatant from MH-S cells were calculated based on a standard curve provided with the commercial kit. Data are expressed as mean \pm SEM.

\section{Statistical analysis}

Statistical comparisons were performed by the paired 2tailed Student's $t$-test. All values are reported as mean \pm SEM, with significance assumed at $\mathrm{p}<0.05$.

\section{Acknowledgements}

We are most indebted to H. R. Muller for helping with the experiments. This work was supported by CNPq. DAS received a grant from CAPES.

\section{Author details}

${ }^{1}$ Instituto de Ciências Biológicas, Universidade Federal de Goiás, 74.001-940 Goiânia, GO, Brazil. ²Programa de Pós-graduação em Ciências Genômicas e Biotecnologia, Universidade Católica de Brasília, 70790-160, Brasília, DF, Brazil. ${ }^{3}$ Departamento de Biologia Celular, Universidade de Brasília, 70910-900, Brasília, DF, Brazil.

\section{Authors' contributions}

DAS carried out the co-cultured cell studies, and drafted the manuscript. RVA participated in the transcription analysis experiments and drafted the manuscript. SSS carried out the co-cultured cell experiments. ALB carried out the immunoassays and drafted the manuscript. MSSF participated in the design of the study and drafted the manuscript. SP conceived the study, performed the statistical analysis, participated in its design and coordination. All authors read and approved the final manuscript.

Received: 31 May 2010 Accepted: 15 September 2010

Published: 15 September 2010

\section{References}

1. San-Blas G, Nino-Vega G: Paracoccidioides brasiliensis: virulence and host response. In Fungal pathogenesis: principles and clinical applications. Edited by: Cihlar RL, Calderone RA. New York: Marcel Dekker; 2001:205-242.

2. Restrepo A, McEwen JG, Castañeda E: The habitat of Paracoccidioides brasiliensis: how far from solving the riddle? Med Mycol 2001, 39:233-241. 
3. Ghannoum MA: Potential role of phospholipases in virulence and fungal pathogenesis. Clin Microbiol Rev 2000, 13:122-143.

4. Mukherjee PK, Chandra J, Kuhn DM, Ghannoum MA: Differential expression of Candida albicans phospholipase B (PLB1) under various environmental and physiological conditions. Microbiology 2003, 149:261-267.

5. Ma L, Xie LX, Dong XG, Shi WY: Virulence of extracellular phospholipase $B$ of Candida albicans in rabbit experimental keratomycosis. Zhonghua Yan Ke Za Zhi 2008, 44:237-243.

6. Chen SC, Muller M, Zhou JZ, Wright LC, Sorrell TC: Phospholipase activity in Cryptococcus neoformans: a new virulence factor? J Infect Dis 1997, 175:414-420

7. Chen SC, Wright LC, Golding JC, Sorrell TC: Purification and characterization of secretory phospholipase B, lysophospholipase and lysophospholipase/transacylase from a virulent strain of the pathogenic fungus Cryptococcus neoformans. Biochem J 2000, 347:431-439.

8. Santangelo R, Zoellner H, Sorrell T, Wilson C, Donald C, Djordjevic J, Shounan Y, Wright L: Role of extracellular phospholipases and mononuclear phagocytes in dissemination of cryptococcosis in a murine model. Infect Immun 2004, 72:2229-2239.

9. Ganendren R, Carter E, Sorrell T, Widmer F, Wright L: Phospholipase B activity enhances adhesion of Cryptococcus neoformans to a human lung epithelial cell line. Microbes Infect 2006, 8:1006-1015.

10. Cox GM, McDade HC, Chen SC, Tucker SC, Gottfredsson M, Wright LC, Sorrell TC, Leidich SD, Casadevall A, Ghannoum MA, Perfect JR: Extracellular phospholipase activity is a virulence factor for Cryptococcus neoformans. Mol Microbiol 2001, 39:166-175.

11. Karkowska-Kuleta J, Rapala-Kozik M, Kozik A: Fungi pathogenic to humans: molecular bases of virulence of Candida albicans, Cryptococcus neoformans and Aspergillus fumigatus. Acta Biochim Pol 2009, 56:211-224.

12. Assis CM, Gambale W, Paula CR: Production of proteinase and phospholipase by Paracoccidioides brasiliensis. Mycopathologia 1999, 146:13-17.

13. Tavares $\mathrm{AH}$, Silva SS, Bernades W, Maranhão $\mathrm{AQ}$, Kyaw CM, PoçasFonseca M, Silva-Pereira I: Virulence insights from the Paracoccidioides brasiliensis transcriptome. Genet Mol Res 2005, 4:372-389.

14. Schmiel DH, Miller VL: Bacterial phospholipases and pathogenesis. Microbes Infect 1999, 1:1103-1112.

15. Noverr MC, Cox GM, Perfect JR, Huffnagle GB: Role of $P L B 1$ in pulmonary inflammation and cryptococcal eicosanoid production. Infect Immun 2003, 71:1538-1547.

16. Felipe MS, Andrade RV, Arraes FB, Nicola AM, Maranhão AQ, Torres FA, Silva-Pereira I, Poças-Fonseca MJ, Campos EG, Moraes LM, Andrade PA, Tavares AH, Silva SS, Kyaw CM, Souza DP, Pereira M, Jesuíno RS, Andrade EV, Parente JA, Oliveira GS, Barbosa MS, Martins NF, Fachin AL, Cardoso RS, Passos GA, Almeida NF, Walter ME, Soares CM, Carvalho MJ, Brígido MM: Transcriptional profiles of the human pathogenic fungus Paracoccidioides brasiliensis in mycelium and yeast cells. J Biol Chem 2005, 280:24706-24714.

17. Ganendren R, Widmer F, Singhal V, Wilson C, Sorrell T, Wright L: In vitro antifungal activities of inhibitors of phospholipases from the fungal pathogen Cryptococcus neoformans. Antimicrob Agents Chemother 2004 48:1561-1569.

18. Tavares AH, Silva SS, Dantas A, Campos EG, Andrade RV, Maranhão AQ Brígido MM, Passos-Silva DG, Fachin AL, Teixeira SM, Passos GA, Soares CM, Bocca AL, Carvalho MJ, Silva-Pereira I, Felipe MS: Early transcriptional response of Paracoccidioides brasiliensis upon internalization by murine macrophages. Microbes Infect 2007, 9:583-590

19. Dantas AS, Andrade RV, Carvalho MJ, Felipe MS, Campos EG: Oxidative stress response in Paracoccidioides brasiliensis: assessing catalase and cytochrome c peroxidase. Mycol Res 2008, 112:747-756.

20. Finlay BB, Falkow S: Common themes in microbial pathogenicity revisited. Microbiol Mol Biol Rev 1997, 61:136-169.

21. Lorenz MC, Fink GR: The glyoxylate cycle is required for fungal virulence. Nature 2001, 412:83-86.

22. Derengowski LS, Tavares AH, Silva S, Procópio LS, Felipe MS, Silva-Pereira I: Upregulation of glyoxylate cycle genes upon Paracoccidioides brasiliensis internalization by murine macrophages and in vitro nutritional stress condition. Med Mycol 2008, 46:125-134.

23. Zambuzzi-Carvalho PF, Cruz AH, Santos-Silva LK, Goes AM, Soares CM, Pereira M: The malate synthase of Paracoccidioides brasiliensis $\mathrm{Pb01}$ is required in the glyoxylate cycle and in the allantoin degradation pathway. Med Mycol 2009, 4:1-12.

24. Silva SS, Tavares AH, Passos-Silva DG, Fachin AL, Teixeira SM, Soares CM, Carvalho MJ, Bocca AL, Silva-Pereira I, Passos GA, Felipe MS: Transcriptional response of murine macrophages upon infection with opsonized Paracoccidioides brasiliensis yeast cells. Microbes Infect 2008, 10:12-20.

25. Medzhitov R, Janeway CA Jr: Decoding the patterns of self and nonself by the innate immune system. Science 2002, 296:298-300.

26. Bonfim CV, Mamoni RL, Blotta MH: TLR-2, TLR-4 and dectin-1 expression in human monocytes and neutrophils stimulated by Paracoccidioides brasiliensis. Med Mycol 2009, 47:722-733.

27. Jiménez D, Roda-Navarro P, Springer TA, Casasnovas JM: Contribution of Nlinked glycans to the conformation and function of intercellular adhesion molecules (ICAMs). J Biol Chem 2005, 280:5854-5861.

28. Romani L: Immunity to fungal infections. Nat Rev Immunol 2004, 4:1-23.

29. Kashino SS, Fazioli RA, Cafalli-Favati C, Meloni-Bruneri LH, Vaz CA, Burger E, Singer LM, Calich VL: Resistance to Paracoccidioides brasiliensis infection is linked to a preferential Th1 immune response, whereas susceptibility is associated with absence of IFN-gamma production. I Interferon Cytokine Res 2000, 20:89-97.

30. Calich VL, Pina A, Felonato M, Bernardino S, Costa TA, Loures FV: Toll-like receptors and fungal infections: the role of TLR2, TLR4 and MyD88 in paracoccidioidomycosis. FEMS Immunol Med Microbiol 2008, 53:1-7.

31. Brummer E, Hanson LH, Restrepo A, Stevens DA: Intracellular multiplication of Paracoccidioides brasiliensis in macrophages: killing and restriction of multiplication by activated macrophages. Infect Immun 1989, 57:2289-2294.

32. Monahan J, Gewirth AA, Nuzzo RG: Indirect fluorescence detection of simple sugars via high-pH electrophoresis in poly(dimethylsiloxane) microfluidic chips. Electrophoresis 2002, 14:2347-2354.

doi:10.1186/1471-2180-10-241

Cite this article as: Soares et al.: Extracellular Paracoccidioides brasiliensis phospholipase $\mathrm{B}$ involvement in alveolar macrophage interaction. $B M C$ Microbiology 2010 10:241.

\section{Submit your next manuscript to BioMed Central and take full advantage of:}

- Convenient online submission

- Thorough peer review

- No space constraints or color figure charges

- Immediate publication on acceptance

- Inclusion in PubMed, CAS, Scopus and Google Scholar

- Research which is freely available for redistribution 